\title{
Workers' Compensation Claim Rates and Costs for Musculoskeletal Disorders Related to Overexertion Among Construction Workers - Ohio, 2007-2017
}

\author{
Harpriya Kaur, $\mathrm{PhD}^{1}$; Steven J. Wurzelbacher, $\mathrm{PhD}^{2}$; P. Tim Bushnell, $\mathrm{PhD}^{3}$; James W. Grosch, PhD ${ }^{1}$; Chih-Yu Tseng, MS²; Juliann C. Scholl, PhD ${ }^{1}$; \\ Alysha R. Meyers, $\mathrm{PhD}^{2}$; Michael Lampl, MS ${ }^{4}$
}

Overexertion is a leading cause of work-related musculoskeletal disorders (WMSDs) among construction workers. Nearly $90 \%$ of construction jobs require manual handling of materials for approximately one half of the worker's time (1). In 2015, overexertion from lifting and lowering materials caused $30 \%$ of WMSDs among construction workers; overexertion involving pushing, pulling, holding, carrying, and catching materials caused an additional $37 \%$ of WMSDs (1). This study examined the rate and cost of WMSD claims from overexertion among Ohio construction workers during 2007-2017. Workers' compensation claims related to overexertion that were submitted to the Ohio Bureau of Worker's Compensation (OHBWC) by workers in the construction industry for injuries and illnesses occurring during 2007-2017 were analyzed. Rates and costs of allowed claims were measured by age group. Workers aged 35-44 years experienced the highest claim rate: 63 per 10,000 full-time employees (FTEs) for WMSDs from overexertion. However, claims by workers aged 45-54 years and 55-64 years were more costly on average and resulted in more days away from work. Ergonomic design improvements and interventions are needed to ensure that the majority of construction workers can safely perform jobs throughout their careers. Age-specific WMSD prevention and risk communication efforts also might be helpful.

From 1985 to 2015, the average age of construction workers increased from 36 years to 42.5 years (2). As workers age, they become more susceptible to losing muscle mass and strength (3). These and other age-related physical changes can affect workers' ability to perform physically demanding tasks, their vulnerability to WMSDs, and their ability to recover from WMSDs. As the U.S. workforce grows older, understanding the age-specific health and safety needs of workers is critical, especially in hazardous and physically demanding industries such as construction.
Data for this report came from workers' compensation claims for WMSDs filed by employees of state-insured private industry employers in Ohio* during 2007-2017. Ohio is the most populous of the four states (North Dakota, Ohio, Washington, and Wyoming) that have exclusive state-run workers' compensation systems. Ohio insures approximately two thirds of the state's workforce. In Ohio, only large employers (usually those with $\geq 500$ employees) may self-insure. Lost-time claims (those with $\geq 8$ days away from work) and medical-only claims (only

\footnotetext{
*All worker compensation claims were from OHBWC-insured, single- and multiple-location private industry employers. Large employers (usually with $\geq 500$ employees) have the option to self-insure if they meet certain requirements. In $2017,54 \%$ of those employers were estimated to have done so. Owners of sole proprietorships and partnerships do not have to insure themselves but must insure any employees they have. In $2017,38 \%$ of sole proprietorships did not purchase OHBWC coverage.
}

\section{INSIDE \\ 583 Airport Traveler Testing Program for SARS-CoV-2 - Alaska, June-November 2020 \\ 589 COVID-19 Outbreaks in Correctional Facilities with Work-Release Programs — Idaho, July-November 2020 \\ 595 Laboratory Modeling of SARS-CoV-2 Exposure Reduction Through Physically Distanced Seating in Aircraft Cabins Using Bacteriophage Aerosol - November 2020 \\ 600 Notes from the Field: Multistate Outbreak of Escherichia coli 026 Infections Linked to Raw Flour - United States, 2019 \\ 602 QuickStats}

Continuing Education examination available at https://www.cdc.gov/mmwr/mmwr_continuingEducation.html

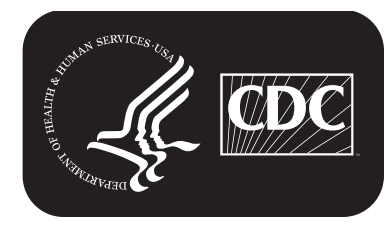

U.S. Department of Health and Human Services Centers for Disease Control and Prevention 
medical treatment expenses paid and $\leq 7$ lost work days) were analyzed. Claim data fields included employer information, worker age and gender, claim cost, lost work days, diagnosis billing codes (International Classification of Diseases, Ninth Revision, Clinical Modification [ICD-9-CM]), and a free-text narrative that described how the injury or illness occurred.

All claim narratives were auto-coded using two algorithms $(4,5)$. The first algorithm identified claims that met the U.S. Bureau of Labor Statistics (BLS) case definition for a WMSD. ${ }^{\dagger}$ The second algorithm identified a subset of WMSD claims that met the BLS Occupational Injury and Illness Classification System definition for overexertion involving an outside source. $\$$ High-cost (95th percentile or higher) claims and lost-time claims with low estimated probabilities of an accurately autocoded diagnosis were manually reviewed by expert coders. When a claim had multiple ICD-9-CM diagnosis codes, an OHBWC algorithm was used to identify the diagnosis most likely to keep the worker off work for the longest period.

\footnotetext{
$\dagger$ This analysis used a definition for musculoskeletal disorders that included Raynaud's phenomenon, tarsal tunnel syndrome, and herniated spinal discs, similar to the revised BLS case definition (2011 and forward). https://www.bls.gov/iif/oshdef.htm

$\$$ According to the Occupational Injury and Illness Classification System, overexertion involving outside sources (code 71), "applies to cases, usually non-impact, in which the injury or illness resulted from excessive physical effort directed at an outside source of injury or illness." Typically, an outside source refers to anything or any person against which the worker exerted force during the bodily motions thought to have caused the WMSD. This could involve, for example, pushing, pulling, or lifting. https://www.bls.gov/iif/osh_ oiics_2010_2_4.pdf
}

Worker's compensation claims were linked to Ohio unemployment insurance data to determine employer industry and employee count using methods developed by previous studies (6). The construction industry was identified by North American Industry Classification System code 23.9 American Community Survey** yearly data contain information on number of hours worked per construction worker and were used to convert number of employees to number of FTEs. American Community Survey data also were used to estimate the percentage of the Ohio construction worker population within each age group, which was used to calculate age-specific rates. Cumulative claim rates were calculated by dividing the sum of the yearly claim counts by the sum of the yearly estimated FTEs for 2007-2017.

The most recently estimated total costs ${ }^{\dagger \dagger}$ were used to calculate cost per claim and cost per FTE by age group. The number of lost work days associated with each claim was the number recorded as of June 30, 2019. $\$ \$$ For each age group, the percentage of claims that were lost-time claims and the

\footnotetext{
https://www.naics.com/six-digit-naics/?code=23

** https://www.census.gov/programs-surveys/acs

$\dagger \dagger$ Costs were total incurred costs (not adjusted for inflation) as of June 30, 2019.

Those include all costs for medical treatments and indemnity (partial lost wage replacement) paid up to that time, plus the amount set aside for reserves to pay projected future costs of the same set of claims. The costs of some claims for WMSDs occurring during 2007-2017 had not all been paid as of 2019 because some workers were still receiving medical care for the WMSD or were still entitled to indemnity payments to compensate for ongoing or recurring loss of work.

$\$ \$$ The eventual total number of days lost is not known for those claims for which work days were lost after 2019.
}

The MMWR series of publications is published by the Center for Surveillance, Epidemiology, and Laboratory Services, Centers for Disease Control and Prevention (CDC), U.S. Department of Health and Human Services, Atlanta, GA 30329-4027.

Suggested citation: [Author names; first three, then et al., if more than six.] [Report title]. MMWR Morb Mortal Wkly Rep 2021;70:[inclusive page numbers].

\section{Centers for Disease Control and Prevention \\ Rochelle P. Walensky, MD, MPH, Director \\ Anne Schuchat, MD, Principal Deputy Director \\ Daniel B. Jernigan, MD, MPH, Acting Deputy Director for Public Health Science and Surveillance \\ Rebecca Bunnell, PhD, MEd, Director, Office of Science \\ Jennifer Layden, MD, PhD, Deputy Director, Office of Science \\ Michael F. Iademarco, MD, MPH, Director, Center for Surveillance, Epidemiology, and Laboratory Services}

MMWR Editorial and Production Staff (Weekly)

\footnotetext{
Charlotte K. Kent, PhD, MPH, Editor in Chief Jacqueline Gindler, MD, Editor

Brian A. King, PhD, MPH, Guest Science Editor

Paul Z. Siegel, MD, MPH, Associate Editor

Mary Dott, MD, MPH, Online Editor

Terisa F. Rutledge, Managing Editor

Teresa M. Hood, MS, Acting Lead Technical Writer-Editor

Glenn Damon, Soumya Dunworth, PhD,

Catherine B. Lansdowne, MS, Donald G. Meadows, MA,

Srila Sen, MA, Stacy Simon, MA, Jeffrey D. Sokolow, MA, Technical Writer-Editors

Matthew L. Boulton, MD, MPH

Carolyn Brooks, ScD, MA

Jay C. Butler, MD

Virginia A. Caine, MD

Jonathan E. Fielding, MD, MPH, MBA

David W. Fleming, MD
}

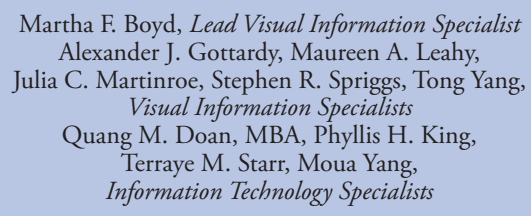

Martha F. Boyd, Lead Visual Information Specialist Alexander J. Gottardy, Maureen A. Leahy,

Julia C. Martinroe, Stephen R. Spriggs, Tong Yang, Visual Information Specialists

Quang M. Doan, MBA, Phyllis H. King,

Terraye M. Starr, Moua Yang,

Information Technology Specialists

Ian Branam, MA, Acting Lead

Health Communication Specialist Shelton Bartley, MPH,

Lowery Johnson, Amanda Ray,

Jacqueline N. Sanchez, MS,

Health Communication Specialists Will Yang, MA,

Visual Information Specialist 
percentage of lost-time claims with $\geq 100$ lost work days were calculated as indicators of claim severity. SAS (version 9.4; SAS Institute) was used to conduct all analyses. This activity was reviewed by CDC and was conducted consistent with applicable federal law and CDC policy. 99

During 2007-2017, OHBWC accepted 10,347 claims*** from construction workers for WMSDs resulting from overexertion. The rate of WMSD claims per 10,000 FTEs from overexertion among construction workers was highest among those aged 35-44 years (63.0), followed by claim rates among those aged $45-54$ years (59.6) and those aged 25-34 years (55.5). The relationship between WMSD rate and age differed by diagnosis category. The claim rate for spinal disc disorders was highest among those aged 35-44 years (4.7) and 45-54 years (4.5), as was the rate of upper extremity sprains

\footnotetext{
9945 C.F.R. part 46, 21 C.F.R. part 56; 42 U.S.C. Sect. 241 (d); 5 U.S.C. Sect. 552a; 44 U.S.C. Sect. 3501 et seq.

*** This total excludes 95 claims for which age was missing.
}

(18.5 among those aged 35-44 years and 18.6 among those aged 45-54 years). The rate of back sprain claims was highest among those aged 25-34 years (26.5) and 35-44 years (24.6) (Figure).

The severity of WMSDs, as measured by the percentage of claims classified as lost-time ( $\geq 8$ lost work days), increased with age, peaking among those aged 55-64 years (Table 1). The percentage of lost-time claims with $\geq 100$ work days lost was highest among those aged 45-54 years and lowest among those aged 18-24 years. Cost per claim was highest among those aged $45-54$ years $(\$ 25,932)$ and $54-64$ years $(\$ 25,572)$. Cost per FTE was highest among those aged 45-54 years (\$154.56) (Table 2). The relationship between cost and age differed by diagnosis category; for example, cost per FTE for back and lower extremity sprains peaked among those aged 35-44 years and 25-34 years, respectively, whereas spinal disc disorders and upper extremity sprain costs per FTE peaked among those aged 45-54 years and 55-64 years, respectively.

FIGURE. Rate of work-related musculoskeletal disorder claims from overexertion per 10,000 full-time employees among construction workers, by diagnosis category* and age group — Ohio, 2007-2017

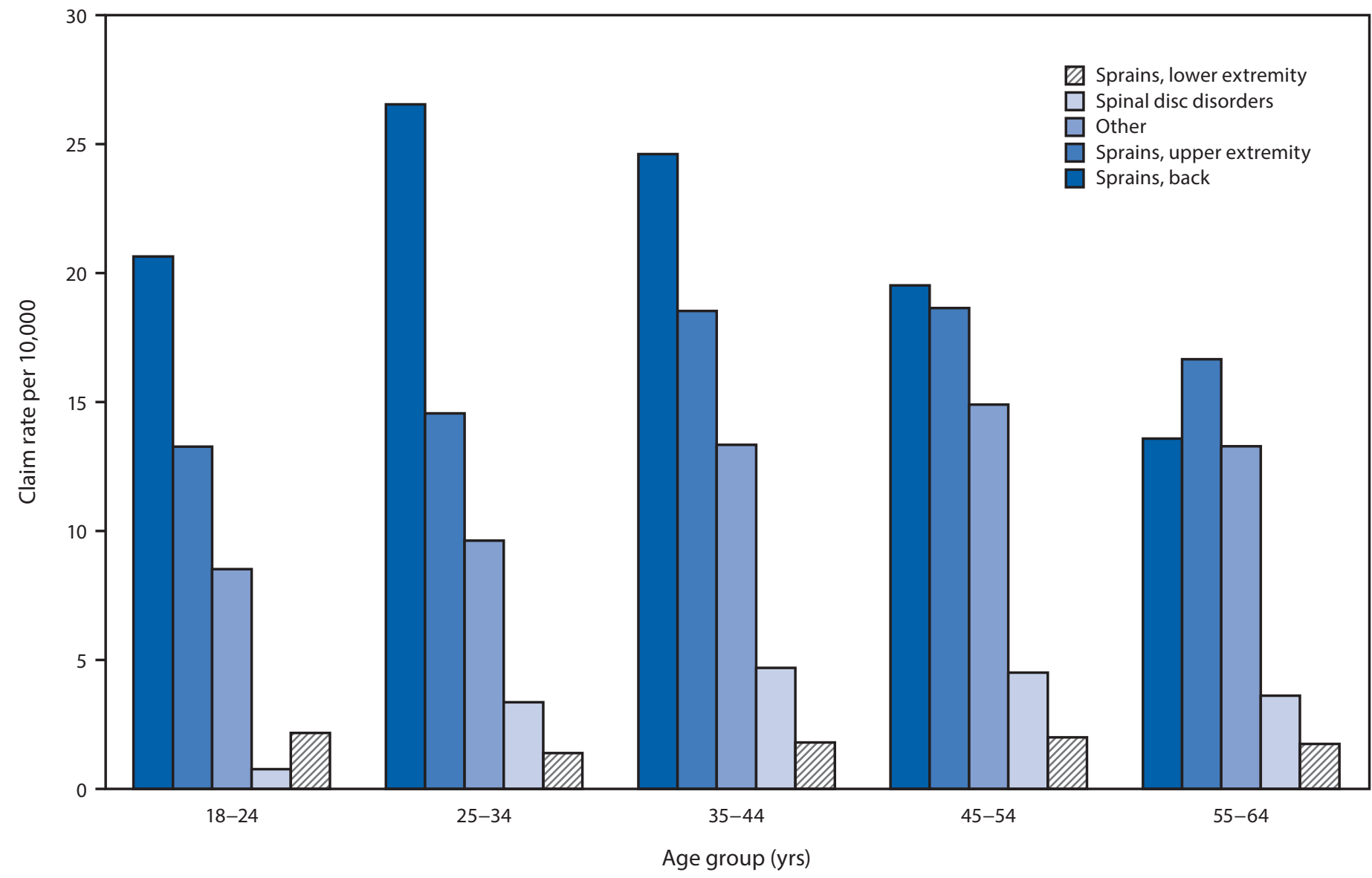

* Among these, $63 \%$ were single diagnoses. For multiple diagnoses, an algorithm was used to identify the diagnosis most limiting the ability to return to work. 
TABLE 1. Age-specific numbers and rates of work-related musculoskeletal disorder (WMSD) claims from overexertion among construction workers - Ohio, 2007-2017

\begin{tabular}{|c|c|c|c|c|c|}
\hline \multirow[b]{2}{*}{ Claim } & \multicolumn{5}{|c|}{ No. of claims, by age group (yrs) } \\
\hline & $18-24$ & $25-34$ & $35-44$ & $45-54$ & $55-64$ \\
\hline Total (all overexertion WMSDs) & 879 & 2,570 & 3,004 & 2,746 & 1,148 \\
\hline \multicolumn{6}{|l|}{ Diagnosis category } \\
\hline Spinal disc disorders & 15 & 156 & 224 & 208 & 85 \\
\hline Upper extremity sprains & 257 & 674 & 884 & 859 & 391 \\
\hline Lower extremity sprains & 42 & 65 & 86 & 92 & 41 \\
\hline Back sprains & 400 & 1,229 & 1,174 & 900 & 319 \\
\hline Other overexertion WMSDs* & 165 & 446 & 636 & 687 & 312 \\
\hline No. of FTEs & 193,702 & 463,026 & 476,862 & 460,729 & 234,751 \\
\hline \multicolumn{6}{|l|}{ Claims per 10,000 FTEs } \\
\hline Total (all overexertion WMSDs) & 45.4 & 55.5 & 63.0 & 59.6 & 48.9 \\
\hline \multicolumn{6}{|l|}{ Diagnosis category } \\
\hline Spinal disc disorders & 0.8 & 3.4 & 4.7 & 4.5 & 3.6 \\
\hline Upper extremity sprains & 13.3 & 14.6 & 18.5 & 18.6 & 16.7 \\
\hline Lower extremity sprains & 2.2 & 1.4 & 1.8 & 2.0 & 1.8 \\
\hline Back sprains & 20.7 & 26.5 & 24.6 & 19.5 & 13.6 \\
\hline Other overexertion WMSDs* & 8.5 & 9.6 & 13.3 & 14.9 & 13.3 \\
\hline \multicolumn{6}{|c|}{ Percentage of claims with high number of lost work days ( $\geq 8$ days, $\geq 100$ days) } \\
\hline Lost-time claims ( $\geq 8$ lost work days) as percentage of all claims & 18.0 & 23.8 & 32.0 & 38.6 & 40.5 \\
\hline Percentage of lost-time claims with $\geq 100$ lost work days & 31.6 & 40.6 & 43.6 & 45.0 & 42.4 \\
\hline
\end{tabular}

Abbreviation: $\mathrm{FTE}=$ full-time employee.

* Other overexertion WMSDs include carpal tunnel syndrome, diseases of musculoskeletal and connective tissues, hernia of abdominal cavity, soft tissue/enthesopathy, other sprains, dislocation, spinal osteoarthritis, diseases of the nervous system and sense organ, injury to nerves and spinal cord, knee derangement, other joint disorders, and symptoms, signs, and ill-defined conditions, not elsewhere classified.

\section{Discussion}

The findings in this report are consistent with those of recent studies indicating that the rate of overexertion-related WMSD claims rise and then fall with increasing age $(7,8)$. This pattern has at least two explanations. First, older workers might shift to other tasks or jobs with reduced WMSD risks. Second, workers experiencing severe pain might move out of the industry, leaving behind a healthier cohort. A longitudinal study among construction roofers found that the odds of leaving the roofing trade early were eight times higher for workers with WMSDs than for workers without such disorders (9). Additional analyses of WMSD rates that include former and current construction workers are needed to determine the actual rates and severity of overexertion-related WMSDs by age group for the construction industry.

The findings in this report are subject to at least three limitations. First, auto-coding methods used to identify WMSD claims entail some misclassification $(4,5)$. Misclassification would not be expected to vary by age if claim records are similar in completeness and accuracy across age groups, but if misclassification varies by type of WMSDs, this could bias the comparison of the mix of WMSDs by age group. Overall, the auto-coding methods have been shown to have positive predictive values $>85 \%$ when compared with manual coding $(4,5)$. Second, not all work injuries and illnesses result in workers' compensation claims. For example, one study of six states estimated that workers' compensation claims accounted for approximately $65 \%$ to $95 \%$ of work-related lost-time cases ( $>3$ or $>7$ lost work days) (10). Underreporting of WMSDs might differ by age group. Finally, data in Ohio are available only for insured private companies; therefore, the degree to which these results reflect age patterns among large, self-insured employers who do not purchase workers' compensation policies is uncertain.

WMSDs affect Ohio construction workers of all age groups, but do so differently. As age increases, the severity of WMSDs appears to rise, and the relative frequencies of WMSD types change. This suggests the potential usefulness of targeting some prevention efforts specifically to the needs of older workers. For example, differences between age groups in the rate and severity of specific WMSD types might be communicated to workers and their supervisors to help them focus on the most important risks. Considering the high rates of WMSDs among workers aged 25-44 years, and the fact that construction workers with WMSDs tend to leave the workforce prematurely (2), workplace ergonomic design and interventions for workers of all ages should be considered. These measures include modifying tasks, promoting the use of ergonomic tools and equipment, providing training in safe work practices, and other interventions. ${ }^{\dagger \dagger}{ }^{\dagger}$, \$S\$

\footnotetext{
††† https://www.cpwr.com/research/research-practice-library/ construction-ergonomic-research-solutions

$\$ \$ \$$ https://www.lhsfna.org/index.cfm/occupational-safety-and-health/ergonom ics/?PAGENUM=1\&WIPECACHE=false
} 
TABLE 2. Age-specific costs of work-related musculoskeletal disorder (WMSD) claims from overexertion among construction workers, by diagnosis - Ohio, 2007-2017

\begin{tabular}{|c|c|c|c|c|c|}
\hline \multirow[b]{2}{*}{ Claim } & \multicolumn{5}{|c|}{ Cost per claim $(\$),{ }^{*}$ by age group (yrs) } \\
\hline & $18-24$ & $25-34$ & $35-44$ & $45-54$ & $55-64$ \\
\hline Medical incurred cost (all diagnoses) & 2,031 & 5,893 & 9,611 & 11,471 & 10,446 \\
\hline $\begin{array}{l}\text { Medical cost by diagnosis category } \\
\text { Spinal disc disorders } \\
\text { Upper extremity sprains } \\
\text { Lower extremity sprains } \\
\text { Back sprain } \\
\text { Other overexertion WMSDs }{ }^{\dagger}\end{array}$ & $\begin{array}{r}22,272 \\
1,462 \\
1,269 \\
1,102 \\
3,522\end{array}$ & $\begin{array}{r}58,169 \\
3,195 \\
4,240 \\
1,369 \\
4,391\end{array}$ & $\begin{array}{r}66,306 \\
6,216 \\
3,229 \\
2,187 \\
8,927\end{array}$ & $\begin{array}{r}70,422 \\
7,783 \\
2,218 \\
1,918 \\
11,987\end{array}$ & $\begin{array}{r}54,379 \\
9,095 \\
1,604 \\
1,776 \\
10,198\end{array}$ \\
\hline Indemnity incurred cost (all diagnoses) & 1,461 & 5,918 & 10,749 & 14,461 & 15,126 \\
\hline $\begin{array}{l}\text { Indemnity incurred cost by diagnosis ca } \\
\text { Disc disorders } \\
\text { Upper extremity sprains } \\
\text { Lower extremity sprains } \\
\text { Back sprain } \\
\text { Other overexertion WMSDs }{ }^{\dagger}\end{array}$ & $\begin{array}{r}26,127 \\
717 \\
586 \\
535 \\
2,847\end{array}$ & $\begin{array}{r}62,991 \\
2,712 \\
3,352 \\
1,088 \\
4,483\end{array}$ & $\begin{array}{r}77,538 \\
5,147 \\
1,507 \\
2,474 \\
11,537\end{array}$ & $\begin{array}{r}90,859 \\
7,500 \\
845 \\
3,764 \\
15,869\end{array}$ & $\begin{array}{r}100,709 \\
10,593 \\
1,322 \\
1,287 \\
13,454\end{array}$ \\
\hline Total cost (all diagnoses) & 3,492 & 11,811 & 20,359 & 25,932 & 25,572 \\
\hline $\begin{array}{l}\text { Total cost by diagnosis category } \\
\text { Spinal disc disorders } \\
\text { Upper extremity sprains } \\
\text { Lower extremity sprains } \\
\text { Back sprain } \\
\text { Other overexertion WMSDs }{ }^{\dagger}\end{array}$ & $\begin{array}{r}48,400 \\
2,179 \\
1,855 \\
1,637 \\
6,369\end{array}$ & $\begin{array}{r}121,159 \\
5,907 \\
7,592 \\
2,457 \\
8,874\end{array}$ & $\begin{array}{r}143,845 \\
11,362 \\
4,736 \\
4,661 \\
20,464\end{array}$ & $\begin{array}{r}161,281 \\
15,284 \\
3,063 \\
5,682 \\
27,857\end{array}$ & $\begin{array}{r}155,088 \\
19,688 \\
2,925 \\
3,062 \\
23,652\end{array}$ \\
\hline Cost per FTE & & & & & \\
\hline Medical incurred cost (all diagnoses) & 9.22 & 32.71 & 60.54 & 68.37 & 51.09 \\
\hline $\begin{array}{l}\text { Medical Incurred cost by diagnosis catec } \\
\text { Spinal disc disorders } \\
\text { Upper extremity sprains } \\
\text { Lower extremity sprains } \\
\text { Back sprain } \\
\text { Other overexertion WMSDs }{ }^{\dagger}\end{array}$ & $\begin{array}{l}1.72 \\
1.94 \\
0.28 \\
2.28 \\
3.00\end{array}$ & $\begin{array}{r}19.60 \\
4.65 \\
0.60 \\
3.63 \\
4.23\end{array}$ & $\begin{array}{r}31.15 \\
11.52 \\
0.58 \\
5.38 \\
11.91\end{array}$ & $\begin{array}{r}31.79 \\
14.51 \\
0.44 \\
3.75 \\
17.87\end{array}$ & $\begin{array}{r}19.69 \\
15.15 \\
0.28 \\
2.41 \\
13.55\end{array}$ \\
\hline Indemnity incurred cost (all diagnoses) & 6.63 & 32.85 & 67.71 & 86.19 & 73.97 \\
\hline $\begin{array}{l}\text { Indemnity incurred cost by diagnosis ca } \\
\text { Spinal disc disorders } \\
\text { Upper extremity sprains } \\
\text { Lower extremity sprains } \\
\text { Back sprain } \\
\text { Other overexertion WMSDs }{ }^{\dagger}\end{array}$ & $\begin{array}{l}2.02 \\
0.95 \\
0.13 \\
1.10 \\
2.42\end{array}$ & $\begin{array}{r}21.22 \\
3.95 \\
0.47 \\
2.89 \\
4.32\end{array}$ & $\begin{array}{r}36.42 \\
9.54 \\
0.27 \\
6.09 \\
15.39\end{array}$ & $\begin{array}{r}41.02 \\
13.98 \\
0.17 \\
7.35 \\
23.66\end{array}$ & $\begin{array}{r}36.47 \\
17.64 \\
0.23 \\
1.75 \\
17.88\end{array}$ \\
\hline Total cost (all diagnoses) & 15.85 & 65.56 & 128.26 & 154.56 & 125.05 \\
\hline $\begin{array}{l}\text { Total cost by diagnosis category } \\
\text { Spinal disc disorders } \\
\text { Upper extremity sprains } \\
\text { Lower extremity sprains } \\
\text { Back sprain } \\
\text { Other overexertion WMSDs }{ }^{\dagger}\end{array}$ & $\begin{array}{l}3.75 \\
2.89 \\
0.40 \\
3.38 \\
5.43\end{array}$ & $\begin{array}{r}40.82 \\
8.60 \\
1.07 \\
6.52 \\
8.55\end{array}$ & $\begin{array}{r}67.57 \\
21.06 \\
0.85 \\
11.48 \\
27.29\end{array}$ & $\begin{array}{r}72.81 \\
28.50 \\
0.61 \\
11.10 \\
41.54\end{array}$ & $\begin{array}{r}56.16 \\
32.79 \\
0.51 \\
4.16 \\
31.43\end{array}$ \\
\hline
\end{tabular}

Abbreviation: $\mathrm{FTE}=$ full-time employee.

* Costs were total incurred costs as of June 30, 2019, which include all costs paid up to that time, plus the amount set aside for reserves to pay projected future costs of the same set of claims.

† Other overexertion WMSDs include carpal tunnel syndrome, diseases of musculoskeletal and connective tissues, hernia of abdominal cavity, soft tissue/enthesopathy, other sprains, dislocation, spinal osteoarthritis, diseases of the nervous system and sense organ, injury to nerves and spinal cord, knee derangement, other joint disorders, and symptoms, signs, and ill-defined conditions, not elsewhere classified.

Corresponding author: Harpriya Kaur, wdo6@cdc.gov, 513-533-8372.

${ }^{1}$ Division of Science Integration, National Institute for Occupational Safety and Health, CDC; ${ }^{2}$ Division of Field Studies and Engineering, National Institute for Occupational Safety and Health, CDC; ${ }^{3}$ Office of the Director, National Institute for Occupational Safety and Health, CDC; ${ }^{4}$ Ohio Bureau of Workers' Compensation, Columbus, Ohio.
All authors have completed and submitted the International Committee of Medical Journal Editors form for disclosure of potential conflicts of interest. No potential conflicts of interest were disclosed. 


\section{Summary}

What is already known about this topic?

Overexertion is the major cause of work-related musculoskeletal disorders (WMSDs) among U.S. construction workers.

What is added by this report?

Although the prevalence of workers' compensation WMSD claims from overexertion among construction workers during 2007-2017 in Ohio was highest among workers aged 35-44 years, the average claim was more costly and resulted in more days away from work among workers aged $45-54$ years and $55-64$ years.

What are the implications for public health practice?

Ergonomic design improvements and interventions are needed to make the workplace safer for workers of all ages. Age-specific WMSD prevention and risk communication efforts also might be helpful.

\section{References}

1. Center for Construction Research and Training. The construction chart book: the U.S. construction industry and its workers. 6th ed. Silver Spring, MD: The Center for Construction Research and Training; 2018. https://www.cpwr.com/wp-content/uploads/publications/The_6th_ Edition_Construction_eChart_Book.pdf

2. Sokas RK, Dong XS, Cain CT. Building a sustainable construction workforce. Int J Environ Res Public Health 2019;16:4202. PMID:31671567 https://doi.org/10.3390/ijerph16214202
3. Schwatka NV, Butler LM, Rosecrance JR. An aging workforce and injury in the construction industry. Epidemiol Rev 2012;34:156-67. PMID:22173940 https://doi.org/10.1093/epirev/mxr020

4. Meyers AR, Al-Tarawneh IS, Wurzelbacher SJ, et al. Applying machine learning to workers' compensation data to identify Industry-specific ergonomic and safety prevention priorities: Ohio, 2001 to 2011. J Occup Environ Med 2018;60:55-73. PMID:28953071 https://doi. org/10.1097/jom.0000000000001162.

5. Bertke SJ, Meyers AR, Wurzelbacher SJ, Measure A, Lampl MP, Robins D. Comparison of methods for auto-coding causation of injury narratives. Accid Anal Prev 2016;88:117-23. PMID:26745274 https:// doi.org/10.1016/j.aap.2015.12.006

6. Wurzelbacher SJ, Al-Tarawneh IS, Meyers AR, et al. Development of methods for using workers' compensation data for surveillance and prevention of occupational injuries among state-insured private employers in Ohio. Am J Ind Med 2016;59:1087-104. PMID:27667651 https://doi.org/10.1002/ajim.22653

7. Wang X, Dong XS, Choi SD, Dement J. Work-related musculoskeletal disorders among construction workers in the United States from 1992 to 2014. Occup Environ Med 2017;74:374-80. PMID:28039200 https://doi.org/10.1136/oemed-2016-103943

8. Holmström E, Engholm G. Musculoskeletal disorders in relation to age and occupation in Swedish construction workers. Am J Ind Med 2003;44:377-84. PMID:14502765 https://doi.org/10.1002/ajim.10281

9. Welch LS, Haile E, Boden LI, Hunting KL. Impact of musculoskeletal and medical conditions on disability retirement-a longitudinal study among construction roofers. Am J Ind Med 2010;53:552-60. PMID:20112256 https://doi.org/10.1002/ajim.20794

10. Boden LI, Ozonoff A. Capture-recapture estimates of nonfatal workplace injuries and illnesses. Ann Epidemiol 2008;18:500-6. PMID:18083542 https://doi.org/10.1016/j.annepidem.2007.11.003 